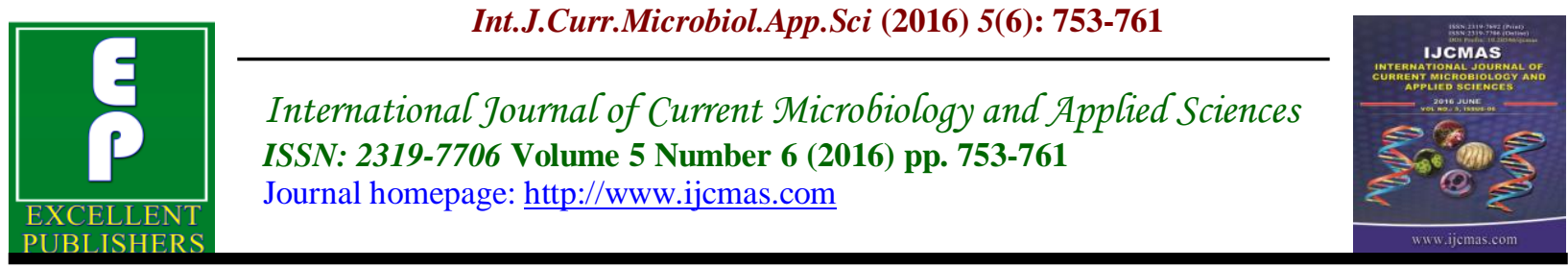

Original Research Article

http://dx.doi.org/10.20546/ijcmas.2016.506.081

\title{
Analysis of Chemical Quality of Ground Water as Source of Drinking Water in Srikakulam District, Andhra Pradesh, India
}

\author{
A. Jyothi ${ }^{1 *}$ and Ch. M. Kumari Chitturi ${ }^{2}$ \\ ${ }^{1}$ Department of Microbiology, Govt. College for Women, Srikakulam, Andhra Pradesh, India \\ ${ }^{2}$ Department of Applied Microbiology Sri Padmavati Mahila Visvavidyalayam (Women's \\ University) Tirupati, India \\ *Corresponding author
}

\begin{tabular}{|c|c|}
\hline & A B S T R A C T \\
\hline $\begin{array}{l}\text { K e y w o r d s } \\
\text { Availability, } \\
\text { non- palatable, } \\
\text { intrusion, } \\
\text { Potable, } \\
\text { Scarcity. }\end{array}$ & \multirow{3}{*}{$\begin{array}{l}\text { Water is vital resource required by living organisms. The demand for water is } \\
\text { increasing with time and this is leading to water scarcity in many parts of the } \\
\text { world. Availability of potable drinking water is essential to human health. In } \\
\text { Srikakulam district most of the inhabitants are depended on ground water has the } \\
\text { major source of drinking water. As this region is close to the sea coast of Bay of } \\
\text { Bengal, the differences in the levels of underground water table due to excess } \\
\text { withdrawals from wells and bore wells may also cause the intrusion of seawater } \\
\text { into the groundwater making non-palatable for drinking. The present study has } \\
\text { been taken up for a period of one year, nearly } 300 \text { plus drinking water samples } \\
\text { from various mandals in srikakulam district, Andhra Pradesh were analysed for } \\
\text { chemical quality to establish its pot ability for drinking purpose, this results were } \\
\text { compared with Indian standard Bureau for evaluation (BIS 10500;2012) and } \\
\text { conclusion. }\end{array}$} \\
\hline Article Info & \\
\hline $\begin{array}{l}\text { Accepted: } \\
\text { 25 May } 2016 \\
\text { Available Online: } \\
\text { 10 June } 2016\end{array}$ & \\
\hline
\end{tabular}

\section{Introduction}

Water is important for all the living forms. Human beings, animals, plants all depend on water for their basic biological activities , human beings basically need for consumption, for house hold activities like cooking, washing and bathing, hence the quality of drinking water should be regularly monitored, Increasing population and its necessities have led to the deterioration of surface and sub surface water ( Shyamala R, Shanthi M, Lalitha P, 2008). Water quality is extremely important because constant access to good quality water is necessary for life as well as the economy (Absalon, D., \& Matysik, M, 2007). India is a agricultural country with one third population depending on underground water for throughout year for cultivation of crops, vegetables and fruits, most villages in India have sparsely have access to underground water supplies due to change in climate, there is depletion in the water table hence it is becoming difficult for those who depend on agriculture for their livelihood. Once ground water gets contaminated, its quality cannot be restored(Vinod Jena, Satish Dixit and 
Sapana Gupta, 2012 ) to its natural form, Groundwater is considered as purest and majorly available source of water and is used to fulfil the $50 \%$ urban and $80 \%$ rural water demand of India besides irrigation. (Sahu P, Sikdar PK, 2008), The quality of groundwater must be checked time to time in order to supply safe drinking water (Cude, C.G., 2001). The Joint Monitoring Programme (JMP) for Water Supply and Sanitation, implemented by the World Health Organisation (WHO) and UNICEF, reports that 783 million people in the world (11\% of the total population) have no access to safe water, $84 \%$ of whom live in rural areas. (World Health Organisation/UNICEF: Geneva, Switzerland; 2012).

With limited access to water supplied by government municipal bodies to the most of the villages in many states in India, people are forced to depend on ground water i.e. wells, ponds, and bore water for their consumption.

However due to difference in mineral composition of the soil where bore well has been dug, it has become difficult to get water in its original pure state and mostly reported many ground water sources are negatively impacted by parameters of aesthetic concern, such as iron, manganese, hardness and total dissolved solids (Feldman PR, Rosenboom JW, Saray M, Navuth P, Samnang C, Iddings S, 2007 )thus making non palatable for drinking, Hence it is necessary for periodic examination of quality of drinking water.

\section{Materials and Methods}

\section{Study Area}

Srikakulam is one of the backward districts of Andhra Pradesh in India. The total area of the District is $5837 \mathrm{Sq}$. Kms .The Nagavali and Vamsadhara are the major rivers in Srikakulam district.

\section{Sample Collection}

In the present study for a period of one year a total of 500 samples water samples were collected randomly over a period from December 2014 to July 2015, from different mandals in Srikakulam district. Water samples were collected in $200 \mathrm{ml}$ capacity sterilized containers from various sources generally bore well supplies and Public water supplies by following standard water collection techniques and immediately transported within two hours to laboratory for analysis.

\section{Chemicals Required}

All the chemicals used are of High Analytical grade from Himedia, Merck, and Fischer.

\section{Procedure}

The Principles of tests are according to Orbit Technologies Kit method, Hyderabad and some are according to principles of titrimetric methods.

\section{Total Alkalinity Test}

The total Alkalinity of water is a measurement of its capacity to neutralize acids, Ground water may contain appreciable amounts of bicarbonates, carbonates, and hydroxide alkalinity, and High alkaline waters are usually unpalatable.

\section{Methodology}

The sample is titrated with sulphuric acid to a colorimetric end point corresponding to a specific $\mathrm{pH}$. Total alkalinity is determined by titration to a $\mathrm{pH}$ of 4.5 by using mixed bromocresol Green methyl red indicator.

\section{Total Hardness Test}

Hard water is generally considered to be that 
water which requires considerable amounts of soap to produce a foam or lather. The hardness of water varies considerably from place to place. In general surface water is softer than ground water. The hardness in water is resulted largely from contact with the soil and rock formations.

\section{Methodology}

After the sample is buffered to $\mathrm{pH} 10.1$ Hardness indicator is added and form wine red complex with portion of the free calcium and magnesium in the sample .Hardness reagent reacts first with free calcium and magnesium ions, then with those bound to the indicator causing it to change to blue colour to the end point.

\section{Calcium Hardness Test}

Calcium hardness is because of the presence of calcium ions in the water. Calcium salts can be readily precipitated from water and high levels of calcium hardness tend to promote scale formation in water systems.

\section{Methodology}

The sample is made alkaline with calcium buffer to precipitate Magnesium as magnesium hydroxide. Calcium indicator is added that combine with calcium to form pink colour. As calcium reagent is added, it reacts with the calcium combined with indicator resulting in a sharp colour change from pink to purple which indicates the endpoint.

\section{Magnesium Hardness Test}

Magnesium is calculated as amount of calcium carbonate present in given water sample.

\section{Fluoride Test}

Water is contact with natural deposits of fluoride such as fluorspar, calcium fluoride and criolite and water contaminated by effluents from glass and aluminium manufacturing industries are found to contain excess fluoride, In India alone about 30 million people are suffering from fluorosis. Presence of large amount of fluoride $(>1.5 \mathrm{mg} /)$ is associated with dental and skeletal fluorosis and less amount $(<1.0 \mathrm{mg} / \mathrm{l})$ with dental cavities.

\section{Methodology}

Zirconium xylenol orange acts as bleaching agent and forms complex depending on fluoride content in water, fluoride ion breaks the zircon xylenol orange complex to form collarless zirconium fluoride.

\section{Iron Test}

In oxygenated surface water iron concentrations are less. Some ground waters may contain considerably more iron; a bitter sweet astringent taste is detectable at levels above $1 \mathrm{mg} / \mathrm{L}$.

\section{Methodology}

Iron reagent reacts with all soluble iron and most insoluble forms of iron in the sample to produce soluble ferrous iron, this reacts with the 1,10 phenanthroline indicator in the reagent to form orange colour in proportion to the iron concentration.

\section{Nitrate Test}

Nitrate represents the most completely oxidised state of nitrogen commonly found in water, Drinking water containing excessive amounts of nitrate can cause infant methenoglobinemia (blue baby disease). For this reason a maximum concentration level in drinking water has been established as $45 \mathrm{ppm}$ by bureau of Indian standards. 


\section{Methodology}

Cadmium metal reduces nitrates in sample to nitrite. The nitrite ion reacts in acidic medium with sulphanilamide to form an intermediate diazonium salts. The salt couples with NEDA to form a mezanta colored product which is proportional to nitrate concentration.

\section{Results and Discussion}

Assessment of the adequacy of the chemical quality of drinking-water relies on comparison of the results of water quality analysis with guideline values (World
Health Organization; 2006), the results of this study were compared with water quality standards by Bureau of Indian Standards, ISO 10500:2012. This work mainly focuses on elaboration of lowest and highest level of contamination present in the ground water in the selected study area, it has been shown that all the chemical parameters have crossed beyond permissible limits as given by BIS, ISO10500:200 with maximum amount of contamination and hence proving unfit for drinking purposes however this study was restricted only to few selected habitations in the given mandals and results are only based on those selected habitation.

Table.1 Drinking water quality standards according to BIS ISO10500:2012.

(Bureau of Indian Standards; 2012; Specification for drinking water. IS: 10500,

New Delhi, India)

\begin{tabular}{|l|l|l|l|}
\hline Sno & Chemical parameter & $\begin{array}{l}\text { Requirement } \\
\text { Permissible limits }\end{array}$ & $\begin{array}{l}\text { Acceptable limit ( In ref to } \\
\text { absence of other source }\end{array}$ \\
\hline 1 & Calcium (as Ca), mg/l & Max 75 & 200 \\
\hline 2 & Chloride (as Cl), mg/l & Max 250 & 1000 \\
\hline 3 & Fluoride (as F),mg/l & Max 1.0 & 1.5 \\
\hline 4 & $\begin{array}{l}\text { Magnesium (as Mg), } \\
\text { mg/l Max 30 }\end{array}$ & 100 \\
\hline 5 & Nitrate (as NO3 ), mg/l & Max 45 & No relaxation \\
\hline 6 & $\begin{array}{l}\text { Total alkalinity as } \\
\text { calcium carbonate, mg/l }\end{array}$ & Max 200 & 60 \\
\hline 7 & $\begin{array}{l}\text { Total hardness (as } \\
\text { CaCO3 ) }\end{array}$ & 600 \\
\hline 8. & Iron (as Fe), mg/l, & Max 0.3 & No relaxation \\
\hline 9. & $\begin{array}{l}\text { Total dissolved solids } \\
\mathrm{mg} / \mathrm{ml}\end{array}$ & 2000 \\
\hline
\end{tabular}


Table.2 Showing minimum and maximum limits of contamination present beyond permissible limits proving to unfit for drinking

\begin{tabular}{|c|c|c|c|c|c|c|c|c|c|}
\hline \multirow[b]{2}{*}{ S.no } & \multicolumn{9}{|c|}{ Mandals in Srikakulam district } \\
\hline & Parameter & Amdalavalasa & Srikakulam & Narrsanapeta & Polaki & Nandigam & Tekkali & Gara & Rajam \\
\hline 1 & Alkalinity & $612-876$ & $640-840$ & $620-900$ & $650-750$ & $650-700$ & \begin{tabular}{|c|}
$640-$ \\
750 \\
\end{tabular} & \begin{tabular}{|l}
$680-$ \\
740 \\
\end{tabular} & $628-968$ \\
\hline 2 & Hardness & $250-750$ & $275-1375$ & $350-500$ & $250-700$ & $250-900$ & \begin{tabular}{|l|}
$250-$ \\
1000 \\
\end{tabular} & $\begin{array}{l}250- \\
750 \\
\end{array}$ & $240-500$ \\
\hline 3 & Chloride & $1152-2080$ & $1008-1068$ & $1100-4500$ & $\begin{array}{l}1300- \\
2100\end{array}$ & $\begin{array}{l}1150- \\
1800\end{array}$ & $\begin{array}{l}1300- \\
2100 \\
\end{array}$ & $\begin{array}{l}1050- \\
4500 \\
\end{array}$ & $1100-2100$ \\
\hline 4 & $\begin{array}{l}\text { Magnesium } \\
\mathrm{Mg}^{+2} \quad \text { as } \\
\mathrm{CaCO} 3\end{array}$ & $10-40$ & $25-225$ & $85-215$ & $80-200$ & $60-300$ & $\begin{array}{l}80- \\
300 \\
\end{array}$ & $70-250$ & $40-250$ \\
\hline 5 & $\begin{array}{l}\text { Calcium } \mathrm{Ca}^{+2} \\
\text { as } \mathrm{CaCO} 3\end{array}$ & $120-300$ & $70-316$ & $300-550$ & $300-600$ & $250-500$ & $\begin{array}{l}180- \\
500\end{array}$ & $\begin{array}{l}300- \\
600\end{array}$ & $120-400$ \\
\hline 6 & Fluoride & $>1.84$ & 1.70 & $>1.70$ & $>1.9$ & 5.2 & 2.90 & $>2.00$ & $>1.8$ \\
\hline 7 & Iron & 0.3-0.7 & $0.3-0.7$ & $0.3-0.8$ & $0.3-0.7$ & $0.3-0.9$ & $\begin{array}{l}0.3- \\
0.9 \\
\end{array}$ & 0.3-1.0 & $0.3-0.8$ \\
\hline 8 & Nitrate & $61-147$ & 90-167 & $66-146$ & $88-147$ & 60-198 & \begin{tabular}{|l|}
$60-$ \\
168 \\
\end{tabular} & 60-197 & $60-146$ \\
\hline 9. & TDS & $2100-5630$ & 2139-3926 & $2100-6773$ & \begin{tabular}{|l}
$2156-$ \\
3856
\end{tabular} & $\begin{array}{c}2444- \\
6864\end{array}$ & \begin{tabular}{|l}
$2104-$ \\
5311
\end{tabular} & \begin{tabular}{|c|}
$2248-$ \\
4868 \\
\end{tabular} & 2138-4179 \\
\hline & \multicolumn{9}{|c|}{$\begin{array}{l}\text { Minimum \& Maximum limits of contamination crossed by chemical parameters in respective mandals, reported as unfit } \\
\text { for drinking }\end{array}$} \\
\hline & usually represe & ted in $\mathrm{mg} / \mathrm{L}$ & during $\mathrm{J}$ & ear 2014-2015 & & & & & \\
\hline
\end{tabular}

Fig.1 Map of Srikakulam District in Andhra Pradesh state in India.

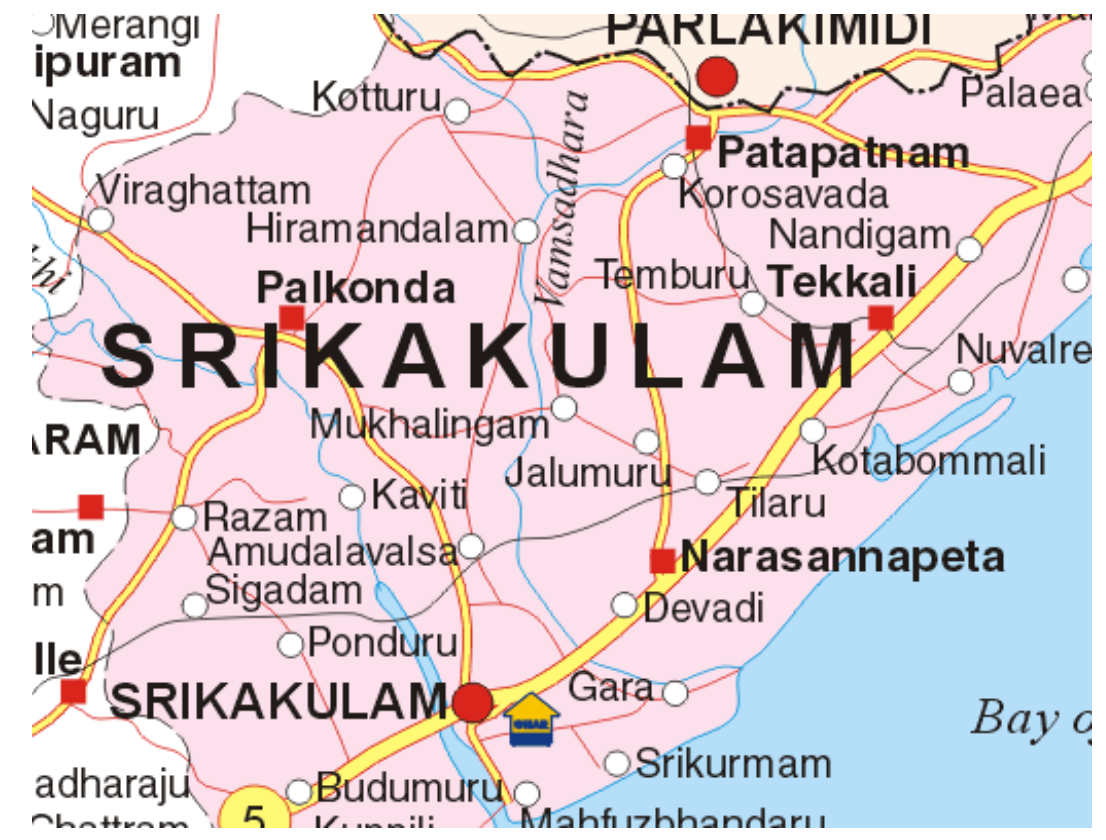




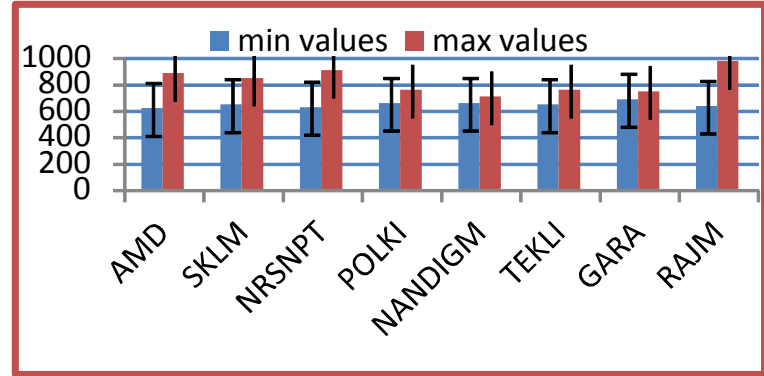

Graph.1 Showing variation in minimum and maximum Limit in alkalinity in given mandals.

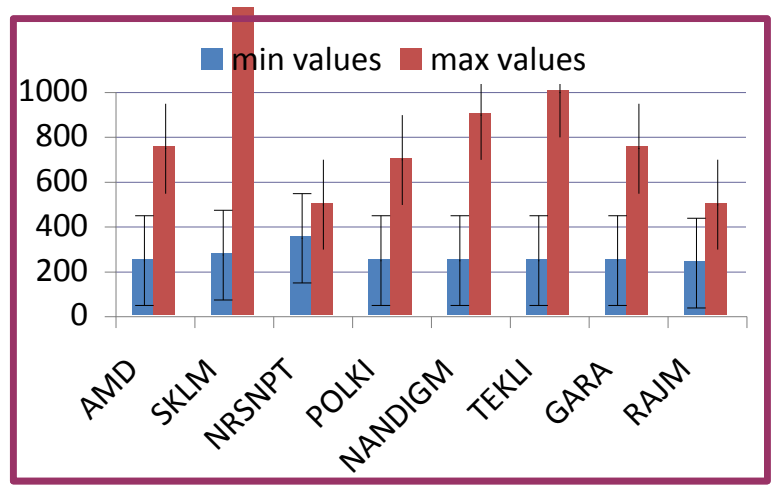

Graph.2 Showing variation in minimum and maximum Limits in Hardness in given mandals.

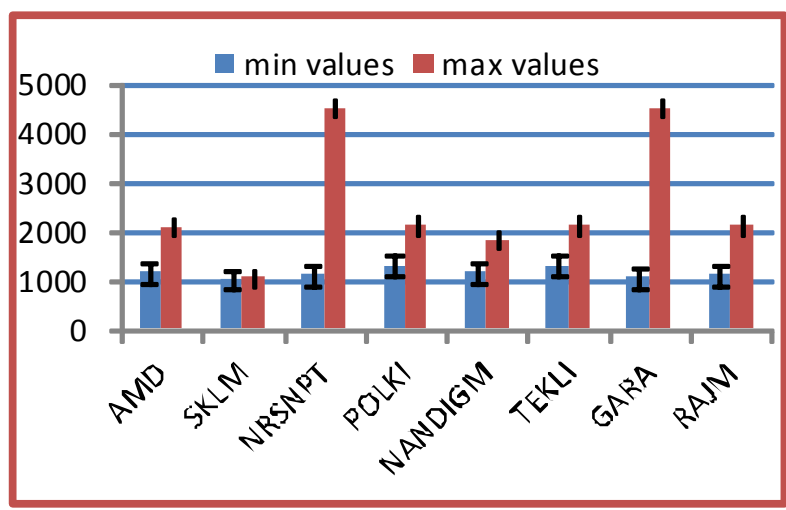

Graph.3 Showing variation in minimum and maximum Limits in Chloride in given mandals 


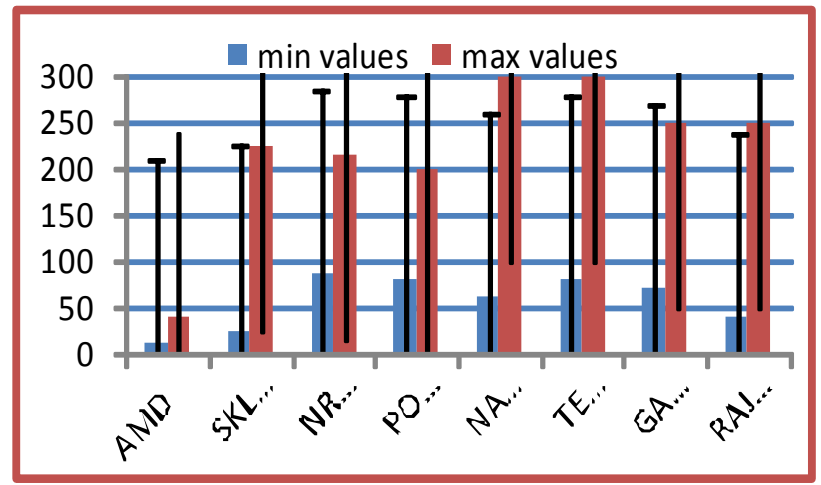

Graph.4 Showing variation in minimum and maximum Limits in Magnesium $\mathrm{Mg}^{+2} \mathrm{as} \mathrm{CaCo}^{3}$ in given mandals

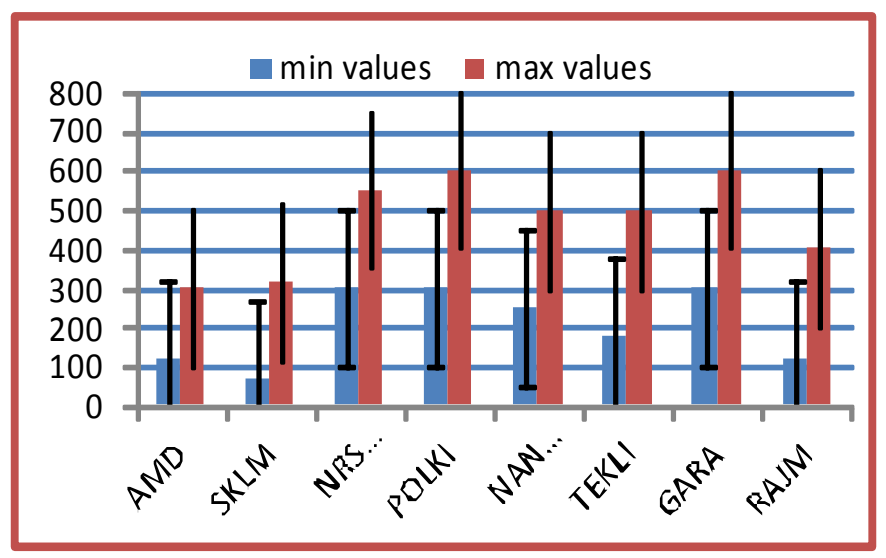

Graph.5 Showing variation in minimum and maximum Limits in Calcium $\mathrm{Ca}^{+2}$ as $\mathrm{CaCo}^{3}$ in given mandals .

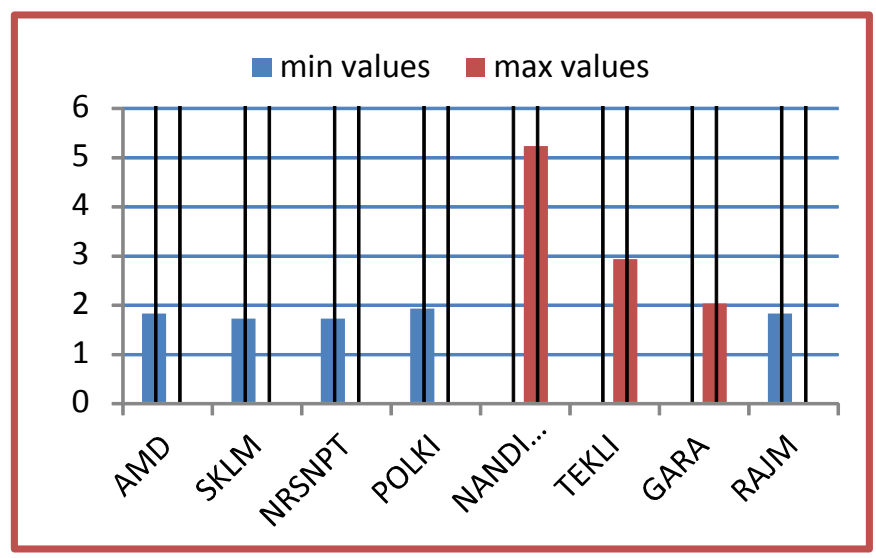

Graph.6 showing variation in minimum and maximum Limits in Fluoride in given mandals 


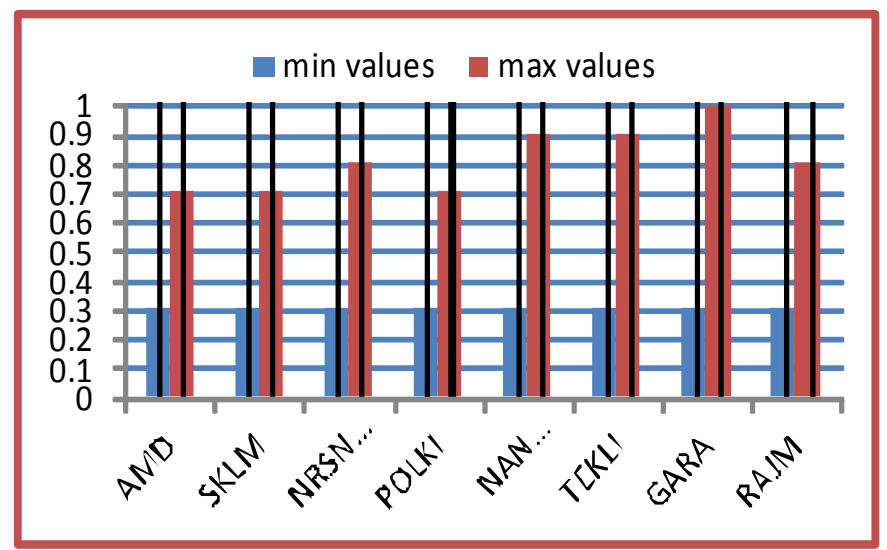

Graph.7 Showing variation in minimum and maximum Limits in Iron in given mandals

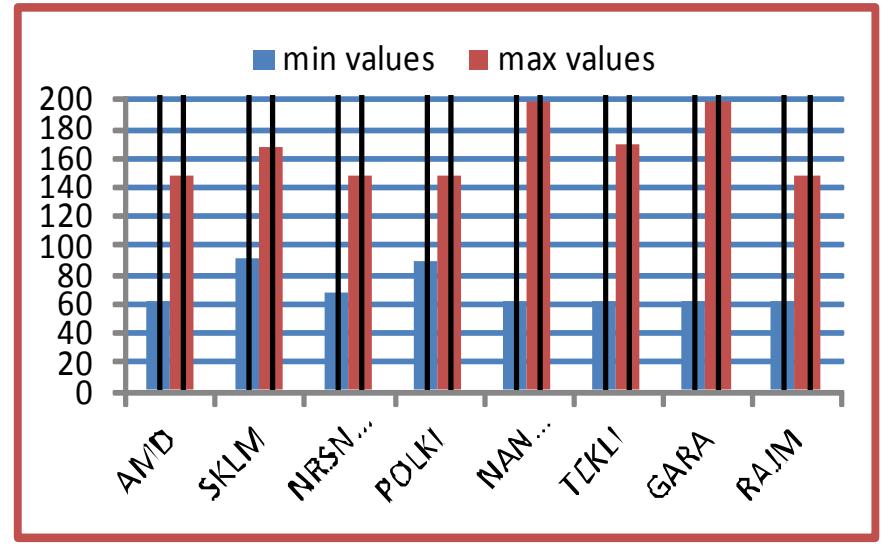

Graph.8 showing variation in minimum and maximum Limits in Nitrate in given mandals

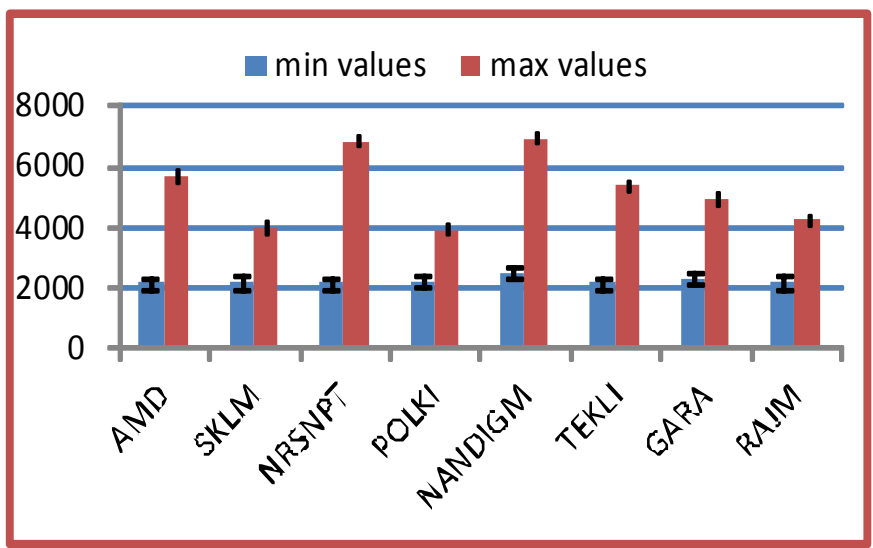

Graph.9 Showing variation in minimum and maximum Limits in TDS in given mandals

This study concludes that most of the habitations in srikakulam district of Andhra
Pradesh state in India are not served with municipal water supply and from 
generations they are depending on ground water as major source for consumption, but as per survey the ground water in these habitations is not fit for drinking because of large number of contamination of chemical parameters, which may lead to health related hazards therefore it is suggested for Government of Andhra Pradesh to take initiative steps for combating these drawbacks and launching programmes for available of municipal water as major source of drinking water for better tomorrow.

\section{Acknowledgement}

The authors are thank full to University grants commission SERO, for providing funding to carry out this minor research project. Ref: F. No: 4-4/2013 -14(MRPSEM/UGC-SERO) dated 17.03.2014, Proposal No 738.

\section{References}

Absalon, D., Matysik, M. 2007. Geomorphol., 92(3-4): 106-118.

Bureau of Indian Standards. 2012. Specification for drinking water. IS: 10500, New Delhi, India.

Curtis, G., Cude. 2001. Oregon water quality index a tool for evaluating water quality management effectiveness. J. American Water Res. Assoc., Volume 37, Issue 1, pages 125-137.
Feldman, P.R., Rosenboom, J.W., Saray, M., Navuth, P., Samnang, C., Iddings, S. 2007. Assessment of the chemical quality of drinking water in Cambodia. J. Water Health. (1):101-16.

Sahu, P., Sikdar, P.K. 2008. Hydro chemical framework of aquifer in and around East Kolkata wetland, West Bengal, India.

Shyamala, R., Shanthi, M., Lalitha, P. 2007. Physicochemical Analysis of Borewell Water Samples of Telungupalayam Area in Coimbatore District, Tamilnadu, India E-J Chem., 5: 924929.

Vinod Jena, Satish Dixit Sapana Gupta. 2012. Comparative study of ground water by physicochemical parameters and water quality index 3(6):14501454 ISSN: 0976-8505 CODEN (USA) CSHIA5 1450 Pelagia Research Library.

WHO. UNICEF. 2012. Progress on Sanitation and Drinking Water: 2012.Update; World Health Organisation/UNICEF: Geneva, Switzerland.

World Health Organization. 2006. Guidelines for drinking-water quality (electronic resource) incorporating first addendum. Vol. 1, Recommendations. - 3rd ed. SBN 92 41546964.

\section{How to cite this article:}

Jyothi, A., and Ch.M. Kumari Chitturi. 2016. Analysis of Chemical Quality of Ground Water as Source of Drinking Water in Srikakulam District, Andhra Pradesh, India. Int.J.Curr.Microbiol.App.Sci. 5(6): 753-761. doi: http://dx.doi.org/10.20546/ijcmas.2016.506.081 